\title{
The Linguistic Analysis of the Structure of the Yoruba Numerals
}

\author{
BABARINDE, Olusanmi (Ph.D) \\ Department of Linguistics and Nigerian Languages, University of Nigeria, Nsukka \\ sbabaride@yahoo.com
}

\begin{abstract}
This paper adopts a descriptive approach in analyzing the counting system of the Yoruba language. It explains the technicalities of its arithmetical involvements which appear to have been contributing to the difficulty often encountered in its learning. The study relies on three major sources in gathering data for the descriptive analysis, namely, compilation of relevant list of Yoruba numerals, the researcher's intuitive knowledge of the language coupled with his training as a linguist, and a search of the relevant literature. The work throws more light on the crucial roles of some affixes in realizing some odd numbers, multiples of twenty, centenary, bicentenary etc in their order of increase. The paper goes much further to examine the linguistic structure of numerals in a bid to bring to light some salient linguistic features that are of significant interest to the teaching of the grammar of the language. Here, we discover that Yoruba numerals derive more of its formation from different aspects of the language structure like sound level (phonology), form/structure level (morphology and syntax), and meaning level (semantics) as evidenced in instances like deletion, assimilation, coalescence, tonal changes, ambiguity, affixation, linguistic typology to mention a few. We also discover that unlike in English, the direction of counting in Yoruba is done from right-to-left. Not only this, it adopts base five, decimal (base ten) and vigesimal systems of counting. This is because the language employs a numeral structure where counting is done mostly in multiples of ogún (twenty). We therefore hope that the detail analysis given in this work will not only fill a gap in the study of the Yoruba language in particular but will also lead to the expansion of Yoruba linguistic database in general. We admit the views of the scholars that linguistic documentation such as this is necessary not only for the study of the language but for the record-keeping of its norm and values which are fast giving way for the impact of technology and domineering influence of the world languages.
\end{abstract}

\section{Introduction}

The traditional system of counting, in any given speech community, constitutes one of the sociolinguistic factors that make up the distinctiveness and individuality of that speech community as against other speech communities. This work sees counting system as a product of human intelligence and limitless of his capacity for indepth thoughtfulness. The fact that every speech community has its own number words used for counting attests the claim that language permeates every aspect of human activities. The purpose of this paper is to examine the traditional system of counting in Yoruba (a New Benue Congo language spoken in the South Western Nigeria). The significance of traditional numerals within the linguistic and pedagogical development of a language, as expressed by Awobuluyi (1994:33), motivates us to write this article. Using the arithmetical phenomenon of base five, decimal (base ten) and vigesimal counting systems, the paper examines the linguistic structure (the phonological, morphological, syntactic and semantic structures) that characterize the derivation of numerals (cardinal and ordinal) in the language. Counting is an indispensable part of man. Whether consciously or unconsciously, counting is what we do each day. In the market (during price haggling), in the farm (during yam storage), in offices and even in our homes, or wherever while taking stock of some items. In fact, counting has been part of man right from creation. Biblically, it is recorded somewhere that may God teach us to count our days so that we might put our minds in the path of wisdom.

Although one may argue that Yoruba is unlikely to be so endangered in the proper sense of the word considering the number of its native speakers and linguistic researches available in the language. However, one of the areas usually identified as being so seriously endangered in the use and study of the language is the numeral system. This is because children nowadays rarely know how to count in Yoruba. Even adults, mix up Yoruba with English when they count money and other objects in the language. It is very shameful if we can do counting in other languages like Arabic and English without a slightest knowledge of how it is obtained in our native language. In the opinion of Comrie $(2005,2006)$, there are many instances of languages that are not particularly endangered, but whose numeral systems are endangered. According to him, language death is the result of social factors and numeral systems or counting generally is particularly susceptible to social factors. (Comrie (2006: 1) illustrates this further:

A community encountering another community with greater numeracy may well borrow the "missing" parts of its system from that other community, but the contact may also involve replacements of parts or all of the existing system, and can also affect languages that come into contact even where there is no great difference in numeracy, but just cultural or commercial superiority of one group over the other. 
This, one would agree with Comrie, explains why numeral systems are more seriously endangered than languages. It has therefore become imperative to document endangered numeral systems before they die out completely. Sadly, Comrie (2006: 1) concludes that given the present rate of death of languages in the world,

"It may well no longer be possible even approximately

to determine what the range of possible numeral systems

in natural language is or to assess what the relative frequency

of different types would be..."

Numeral in whatever language and in whichever forms/patterns it takes is a clear manifestation of the ability of man to manipulate his linguistic resources to cater for his communicative needs. Numerals appear an aspect of language study which researchers, scholars and linguists pay less attention to. This neglect could be connected to certain impression that there is little or nothing else to say about it. Little did we know that there is much to say about this 'little'. Part of our linguistic knowledge is contained in the ability to express our ideas in our mother tongues. Our linguistic knowledge remains insufficient if we are unable to count fluently, analyze how the counting is done, and understand manipulations therein.

This research falls, to a large extent, within the domain of language documentation. It is more or less a new field of study especially in Linguistics in recent time as captured by Woodbury (2003) that this new area is preoccupied with the making and keeping of records of significant features of the world's languages and their pattern of use. The foregoing has invariably given a clear-cut distinction between linguistic documentation and usual linguistic description. According to Himmelmann (1998), one of the ultimate aims of language documentation is the production of a detailed and comprehensive record of the linguistic practices peculiar of a given speech community. He further clarifies the practices as both noticeable linguistic behaviour often made manifest in the speech act of members of the speech community, and the native speakers' metalinguistic intuition that enables them to provide interpretations and systematizations for linguistic units and events.

If indeed the Nigerian Policy on Education - NPE (1977, revised severally up till 2004) which demand that every Nigerian child should be taught all subjects including mathematics in his/her own mother tongue at the early stage of his education is to be accomplished, the need for a thorough understanding of the counting system in our local indigenous languages becomes imperative, especially for the teaching of the number-related subjects.

So, this paper is unique in some ways especially for its mnemonic capacity in the face of the challenges of the 21 st century when we have lost most of our traditional education for lack of documentation coupled with the domineering influence of the English language over the Nigerian languages. The need for this paper derives its strength from the observation of Woodbury (2003: 57) that,

'...most of the traditional norms, values and attributes

(like counting system) of African languages are fast fading away'.

Oyebade (2010) notes that language documentation (in whichever form) could be said to have a close affinity with the languages threatened by extinction. The knowledge of numerals will not only keep our competence in perspective, it will equally serve as a valuable asset in language pedagogy, historical linguistics, the comparative study of African languages and computational linguistics.

This paper seeks to fill a gap in the linguistic study of Yoruba. The work will indeed increase the linguistic database available in the language. The paper does not only look at the technicalities of Yoruba numerals, it further analyzes the linguistic structure of it for the purpose of the enhancement of the teaching and learning of the language. The foregoing justifies Everett (2003) submission on the need to make permanent some significant features of African Linguistics especially her counting system for its theoretical insights to the body of language study. For it will be a colossal loss if it is allowed to be choked up by the thorns of the national, regional and world languages. The primary objective of this study is to contribute to the documentation and description of this most vulnerable aspect of Yoruba grammar by providing a detailed description of its numeral system.

Suffice it to say that in the presentation of data in this work, I make use of the standard Yoruba orthography and IPA symbols especially where a word is rendered in

phonetic transcription. Equally, with respect to tone marks, the acute accent ['] on a tone-bearing segment, usually a vowel and syllabic nasal represents a high tone, all instances where any particular vowel is not tone marked represents the mid tone, and the grave accent ['] on any tone-bearing segment represents a low tone.

\section{A Short Historical Background of Numerals}

In his treatment of the history of numerals, Spencer (1976:4) reports that,

"Primitive tribes were able to keep count of sheep and

other items by using sticks, stones, fingers, notches in

wood, and knots in a string...'

Each language has words that are used for counting. Such number words can be written down in the same way as other words in a language. While giving the diachronic account of numerals, Girling (1958:69-70) makes the assumption that, "Counting is nearly as old as speech and numerals are as old as writing". 
The fact that every speech community has its own number words, in which numerals are written, is confirmed by Mitchell (1976:31) when he presents examples from six European languages to illustrate how numerals are written in number words. The examples are repeated here as Table A:

Table A

\begin{tabular}{|l|l|l|l|l|l|l|}
\hline & ENGLISH & FRENCH & ITALIAN & GERMAN & DUTCH & SPANISH \\
\hline 1. & One & Un & Uno & Ein & Een & Uno \\
\hline 2. & Two & Deux & Due & Zwei & Twee & Dos \\
\hline 3. & Three & Trois & Tre & Drei & Drie & Tres \\
\hline 4. & Four & Quatre & Quattro & Vier & Vier & Cuatro \\
\hline 5. & Five & Cinq & Cinque & Funf & Vijf & Cinco \\
\hline 6. & Six & Six & Sei & Sechs & Zes & Seis \\
\hline 7. & Seven & Sept & Sette & Sieben & Zeven & Siete \\
\hline 8. & Eight & Huit & Otte & Acht & Acht & Ocho \\
\hline 9. & Nine & Neuf & Nove & Neun & Negen & Nuve \\
\hline 10. & Ten & Dix & Dieci & Zehn & Tien & Diez \\
\hline
\end{tabular}

It is not only in the European languages that number words are used; they are also found in all other human languages, as we can find in Table B below:

Table B

\begin{tabular}{|l|l|l|}
\hline & HAUSA & IGBO $^{1}$ \\
\hline 1. & Daya & otu (ofu) \\
\hline 2. & Biyu & Abua \\
\hline 3. & Uku & ato (ito; eto) \\
\hline 4. & Hudu & ano (ino; eno) \\
\hline 5. & Biyar & ise (iso) \\
\hline 6. & Shida & Isii \\
\hline 7. & bakwaii & asaa (isaa; esaa) \\
\hline 8. & takwas & asato ( isato; esato) \\
\hline 9. & Tara & iteghete (itenaani; esato) \\
\hline 10. & Goma & iri (ili) \\
\hline
\end{tabular}

\section{The Concept of Base in Number}

The Oxford English Dictionary, $8^{\text {th }}$ Edition, (1933:102) defines a base as, a number or symbol which is made on the basis of a scale of numeration, or an original word or form from which other words are derived.

In the early stages of development, notes Spencer (1976), the counting process became systematized when it was necessary to make more extensive counts. This was done by arranging the numbers into convenient basic groups, hence the introduction of number bases. Spencer (1976: 42) further observes that:

"Today some South American tribes count by hands, base 5.

The base 12 was used in prehistoric times, chiefly in relation

to measurements. The American Indian and Mayan tribes used

a base 20 number system. The ancient Babylonians used a number

system based on 60 . This system is still used when measuring time and

angles in minutes and seconds. A base, then, is the number of distinct

digits required by a system of numeric notation".

Among the popular types of number bases, Girling (1958:70) recognizes the following:

1) (i) the binary (base two)

(ii) the quaternary (base four)

(iii) the quinary (base five)

(iv) the denary (base ten)

(v) the vigesimal (base twenty)

The decimal system of Arabic numerals (i.e. base 10) that we are most familiar with, was said to have been 
introduced into Europe by Adelard of Bath in about $110 \mathrm{AD}$, and by $1600 \mathrm{AD}$ was in almost universal use (See Mitchcll (1976:31)).

\section{Yoruba Counting System: An Overview}

The counting system will be done under certain headings in consonance with how thing are classified and positioned, i.e. cardinal and ordinal numbers. Cardinal is a term used for the grammatical description referring to the class of numerals like one, two, three etc while ordinal is used to refer to the class of numerals like first, second, third etc. According to Oyebade (2010), numeral system in most African languages is based on either five, decimal (base ten ), or vigesimal (base twenty). For instance, Nupe and Ebira use base five system of counting, Igbo and Esan adopts a decimal system. Yoruba adopts base five, decimal (base ten) and vigesimal counting systems. Lounge (2011) equally observes that the Yoruba language has a rather elaborate vigesimal (base-20) numeral system that involves both addition and subtraction and multiplication. This according to Oduyoye (1969) is exemplified in the habitual counting of fingers in 5, 10 and the toes totaling 20.

\begin{tabular}{|c|c|c|c|}
\hline Arabic & The counting pattern & Cardinals & Ordinals \\
\hline & ení / oókan & ìwé kan (one book) & ipò kìnní= ìèkínní \\
\hline 2 & èjì / eéjì & ,, méjì(two books) &,$\quad$ kejì $=$ ìèkejì \\
\hline 3 & ẹta / ẹéta & , mẹ́ta & , kẹta = i/ẹketa \\
\hline 4 & ệrin / ẹérin & „mẹ́rin & , kẹ́rin= ìẹkkerin \\
\hline 5 & àrún / aárù-ún & „, márùn-ún & , karùn-ún =ìẹ̀karùn-ún \\
\hline 6 & èfà / ẹệà & , mẹ́fà & " kefà $=$ i/ẹ̀kẹfà \\
\hline 7 & èje / eéje & „méje & ", keje $=$ i/èkeje \\
\hline 8 & ẹjọ / ẹẹjọ & „ mẹjọ & „ kejọ = i/ẹkẹjọ \\
\hline 9 & ẹsán / ẹécàn-án & „ mẹ́sàn-án & „, kẹsàn-án=ìẹkẹsàn-án \\
\hline 10 & ẹ̀wá / ẹẹ́wàá & , mẹ́wàá & " kẹwàá=i/ẹkẹwàá \\
\hline $11=10+1$ & ọ̀kànlá / ọọ́kànlá & „, mọ́kànlá & ", kọkànlá=ìẹkkọànlá \\
\hline $12=10+2$ & èjìlá / eéjìlá & „, méjilá & , kejìlá=i/èkejìlá \\
\hline $13=10+3$ & ẹtàlá / ẹ̣tàlá & „mẹ́tàlá & "kẹtàlá=i/ẹ̀kẹtàlá \\
\hline $14=10+4$ & ệrìnlá / ẹérìnlá & „, mẹrìnlá & „, kẹtàlá=i/ẹkẹtàlá \\
\hline $15=20-5$ & àrùndínlógún/aárùndínlógún & „, mẹẹ̀dógún & , karùndínlógún=ìệkarùndínlógún \\
\hline $16=20-4$ & ẹrrìndínlógún/ẹéeìndínlógún & „, mẹrìndínlógún & kẹrìndínlógún=ìẹ̀kẹrìndínlógún \\
\hline $17=20-3$ & ẹtàdínlógún/ẹệtàdínlógún & „, mẹ́tàdínlógún & kẹtàdínlógún=i/ẹkẹtàdínlógún \\
\hline $18=20-2$ & èjìdínlógún/eéjìdínlógún & , méjìdínlógún & „, kejìdínlógún=ìèkejìdínlógún \\
\hline $19=20-1$ & òkàndínlógún/oókàndínlógún & mọkàndínlógùn & kọkàndínlógún=ìẹkọkàndínlógún \\
\hline $20=10+10$ & ogún/okòó & „ogún/ogún ìwé & ipò ogún \\
\hline
\end{tabular}

Note:

$$
\begin{gathered}
11=\text { mọkànlá ( i.e mú ọkan la ẹwa) } \\
\text { take one surpass ten } \\
\text { 'one plus ten (eleven)' } \\
12 \text { = méjilá (i.e mu eéjì la ẹá) } \\
\text { take two surpass ten } \\
\text { 'two plus ten (twelve)' }
\end{gathered}
$$

\section{The Yoruba Counting Techniques}

If we observe closely, we would discover that $6,7,8,9$, and 30, 300, 400 (though not in the sample above, but in the subsequent analysis) are not used recurrently for the derivation of higher numbers. There are conventional terms used to designate 'lesser than' and 'more than'. For instance, 'ó dín.../din ní...' (it reduces/reduces by) is used to count from 15 'mẹẹ̀dógún' (i.e mú-árùn-dí-ní-ogún meaning twenty lesser than five) to 19 'mọ́kàndínlógún' (i.e mú-ọkan-dín-ní-ogún meaning twenty lesser than one). Note that the Yoruba meaning given here are in cardinals. According to Esiri (2011), ogún is the basic word for twenty, okòo the word when counting objects. According to him, each of the decades is coded; units in 1-4 are derived by adding to these, while units in 5-9 are formed by subtracting from the next decade. The odd decades are derived by subtracting ten from the next even decade as found in the Danish language. In other words, 'lé ní...' (increase by...) is from 1 - 4 (i.e adding to 10) while 'ó dín ní...' (decrease by...) is from 5 - 9 (i.e subtracting from 10). The number of increase we count after the previous tens is 4 . In other words, from any number higher than ten, we shall add the first four units to the previous decimal and subtract the next five from the subsequent decimal number as in; 
31 to 34 and so on, we add 1 to 4

while the number of decrease we count before another tens is 5 as in;

$$
\begin{aligned}
& 15 \text { to } 19 \\
& 25 \text { to } 29 \\
& 35 \text { to } 39 \text { and so on. }
\end{aligned}
$$

And the meaning of ten is not seen in twenty. From 21 to 24, the counting pattern changes from what is observed from 11 to 14 . The numbers 11 through 14 are counted in the pattern given in the table above and 21 to 24 are counted as mọ́kànlélógún (i.e. mú-ọkkan-lé-ní-ogún meaning take one more over twenty), méjilélógún (i.e. múèjì-lé-ní-ogún meaning take two more over twenty), mẹtàlélógún (i.e. mú-ẹta-lé-ní-ogún meaning take three more over twenty) and mẹ́rinlélogún (i.e. mú-ẹrin-lé-ní-ogún meaning take four more over twenty) respectively. Apparently, the meanings of the counting from 21 to 24 are not difficult to decipher like numbers 11-12 (see the analysis in section 4.4). From 25 the counting is '...dín lógbọ̀n' (...less than thirty) which means that 25 is 'márùn-ún-dín-ní-ọgbọ̀n/mẹẹ̣oọgbọ̀n' meaning (five lesser than thirty) up to 29 'mộkàndínlọ́gbọ̀n' meaning (one lesser than thirty). 30 is ogbọ̀n. The same procedure is followed in the counting from 31 to 50 . 'ogbọ̀n' as we can note has no semantic connection with either twenty or forty but 40 has. In fact from number 40 henceforth, we start noticing some semantic import of some previous numbers and more importantly, the significance of arithmetic concepts such as division, multiplication, subtraction, addition. 40 is coded ogoji. It means:

\section{(a)}

$$
\begin{aligned}
& 20 \times 2=40(\text { i.e } 20+20) \\
& \text { ogún méjì/èji ogójì/ogún-méjì. }
\end{aligned}
$$

From 50 'àádọ́ta' to 190 'àádọ́wàá', the use of prefix 'àádọ́-' is used to imply 'dín mệwàá' (-10 or less than ten) as against Jeje (1979) who says it is from 50 to 180, as shown below:

(b)

(c)

$$
\begin{array}{ccc}
50 & 60 & 60 \\
\text { àáọ́ta }(\text { i.e } 60-10) & \text { ogọta/ogún mẹ́ta }
\end{array}
$$

$$
\begin{aligned}
& \begin{array}{rr}
(20 \times 3 & -10)
\end{array}
\end{aligned}
$$

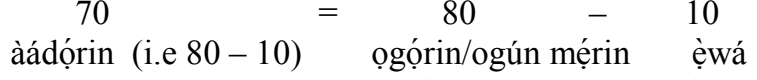

$$
\begin{aligned}
& (20 \times 4-10)
\end{aligned}
$$

$$
90 \quad=100 \quad-10
$$

àádọ́rùn-ún (i.e 100 - 10) ogọorùn-ún/ogún márùn-ún (ẹ̀wá)

The prefix ogó-/ogọ- (i.e. divisible by 20) are used to show figures which are divisible by twenty like;

$$
\begin{aligned}
& \text { - (i.e. divisible by } 20 \text { ) are } \\
& 40 \div 20=2
\end{aligned}
$$

$$
\begin{aligned}
& \text { ogójì/ogún méjì ogún èjì (i.e. } 40 \text { is divisible by } 20 \text { twice) } \\
& 60 \div 20=3 \\
& \text { ogọ́ta/ogún mẹ́ta ogún ẹ̀ta (i.e. } 60 \text { is divisible by } 20 \text { three times) } \\
& 80 \div 20=4
\end{aligned}
$$

Whatever ogó-/ọọ́- or àádọ́- is affixed to can equally be more or less as in:

(h)

$$
\begin{aligned}
& 41 \text { 'mọ́kànlélógójì/mú ọ̀kan lé ní ogójì' (forty increases by one) } \\
& 42 \text { 'méjilélógójì/ mú èji lé ní ogójì (forty increases by two) } \\
& 45 \text { 'márùndínláàdộta/ mú èta lé ní ogójì' (fifty decreases by five) } \\
& 46 \text { 'mệrìndínláàdọta/ múrin lé ní ogójì' (fifty decreases by four) }
\end{aligned}
$$

ogọ́wàá/ogún mẹ́wàa $(20$ x 10) means 200 . It is conventionally coded 'igba'. From (200) above, 20 is no longer expressed as ogún as noted above but as okò as seen in the examples below:

(i) 220 'okòó-lé-ní-igba/okòóléerúgba' (twenty more than 200)

$$
\begin{aligned}
& 280 \text { *`okòó-dín-l-ọọ̣dúnrún’ (twenty lesser than 300) ‘300 is ọọodúnrún’ } \\
& 420 \text { 'okòó-lé-ní-irinwó' (twenty more than 400) '400 is irinwó' } \\
& 480 \text { 'okòó-dín-1-ẹeẹégbẹ̀ta' (twenty lesser than 500) '500 is èẹéégbẹ̀ta' }
\end{aligned}
$$

* See how "ní" in 'dín ní-' (less than) becomes "lọ" in 'dín lọ́’ under denasalization below.

From 500, a new pattern that replaces 10 and 20 with 100 and 200 respectively as computation bases begins. From 500 we change the pattern of counting by prefixing 'ẹẹée-' to any number that is less by 100 . This shows that centuries larger than 200 is derived by either subtracting 100 form the next bicentenary or by multiplying 200 by the appropriate unit as given in the examples below:
(j)
ẹgbẹta/ igba mẹ́ta
(200 x 3)
(k)
800
ẹgbẹrin/igba mẹ́rin
$100=500$
ogọ́rùn-ún/ogún márùn-ún èẹéẹ́-ẹgbẹta
$(200 \times 4)$
$(20 \times 5)$
$(600-100)$
$100=700$
ọọ́rùn-ún/ogún márùn-ún ẹẹẹẹ-ẹgẹ̣rin
(l)
$(20 \times 5)$
$(800-100)$

$1000-100 \quad=\quad 900$




$\begin{array}{lll}\text { ẹgbẹrún/igba márùn-ún } & \text { ogọ́rùn-ún } & \text { èẹ̣dẹ́-ẹgbẹ̀rún } \\ (200 \times 5) & (20 \times 5) & (1000-100)\end{array}$

Whereas 'ẹẹedệ-' is less by 100 , 'ẹgbẹ̀-' (i.e a derivation of igba) is affixed to any number that is divisible by 200 thus:

(m)

(n)

$\begin{array}{ccc}600 \div \quad 200 & =3 \\ \text { ẹbẹta/igba mẹ́ta } & \text { igba } \\ 800 \div 200 & =4\end{array}$

(o)

ẹgeẹ̀rin/igba mẹ́rin igba è̀rin/mẹ́rin

$1000 \div 200=5$

ẹbẹ̀rún/igba márùn-ún igba márùn-ún

As observed in 'ogó-/ọọ́-' (a derivative of ogún) and 'àádọ́-', whatever 'ẹẹedẹ́-' and 'ẹgbẹ̀-' are attached to can equally decrease or increase as shown below:

(p) 502 'ejì-lè-ní-ẹẹdeẹ́-ẹgbẹta' (i.e 600-100 (+2))

540 'òjì-lè-ní-ẹéceẹ-ẹgbẹta' $(600-100(+40))$

620 'okòó-lé-ní-ẹgbẹẹta' $(600+20)$

860 ‘ọtà-lé-lẹgbệrin/òjì-dín-lẹẹedeẹegbẹ̀rún’ $(60$ + 800 / 900 - 40)

955 'àrùn-dín-lẹ́gbẹ̀rún' (1000 - 5)

The secret behind the Yoruba numerals especially at this point is that: we can use 2000 'ẹgbàwá/egbàá-' i.e. igba mẹwàa $(200 \times 10)$ as a prefix attached to describe any figure that is divisible by 2000 thus:

(q)

(r)

(s) $\quad 8000 \div 2000=4$

$$
4000 \div 2000=2
$$

ẹgbàájiẹgbàá méjì ẹgbàá méjì

$6000 \div 2000=3$

ẹgbàáta/ ẹgbàa mẹta ẹgàá mẹ́ta

(t) ẹbàárin/ẹgbàá mẹ́rin ẹgbàá mẹ́rin

ẹgbàárùn-ún/ẹgbàá márùn-ún ẹgbàá márùn-ún

If the number too is equally less by 1000 , we attach 'ẹẹdẹe-' as shown below:
(u)

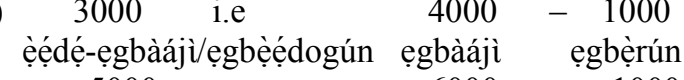
(v)
1000
ẹgbèrún
$-\quad 1000$
ẹgbẹrún
or $200 \times 15$
igba mẹẹedógún
ẹẹdeẹe-ẹgbàáta/ẹgbẹẹéọogbọ̀n ẹgbàata
(w)

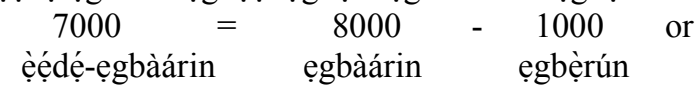
(x)
$9000=$

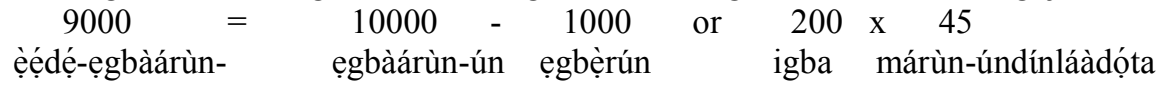
or $200 \times 25$
igba mẹẹeọ́gbọ̀n

The data provided in sections 4 and 5 above reveal that Yoruba adopts both decimal (1 to 10) and vigesimal (multiples of 20 to 200) system of counting. Besides, from the mathematical analysis in section 5, it is evident that Yoruba computes from right-to-left unlike English which computes from left-to-right as typified by the common Hundreds Tens and Unit (HTU). Oyebade (2010) notes that, to a large extent, Yoruba numeral is anticipatory since subtraction is done in the anticipation of the next decimal or centennial number. Yoruba operates subtraction in a base five system and this is done at each decimal junction. This view is aptly captured by Esiri (2011) that the Yoruba Numeral system attests to the system relies heavily on subtraction for derivation of odd numerals. Though there have been some observations, suggestions and proposals aimed at addressing this seemingly complex numeral system. One of such is the adoption of decimal system into the language.

Suffice it to say here that the difficulties and the consequent discouragement that greet the learning and usage of the counting system in Yoruba may not have been unconnected with the mathematical applications therein and the correct use and interpretation of the affixes like àádọ́-, ogó-/ogọo-, ẹẹdẹe-, ẹgbẹ̀-, ẹgbẹẹ-, ẹgbàá etc.

Even the use of base five as a computing strategy for decimals with the sequence reverse equally contributes in some way to its frustrating nature. This observation is aptly captured by Awobuluyi (1994) that the derivation of numerals in most African languages is quite tiresome and complicated.

\section{The Linguistic Analysis of the Yoruba Numerals}

The structure of any language is amenable to three different levels viz, sound level (phonology), form/structure level (morphology and syntax) and meaning level (semantics). There are issues of linguistic interest in the numerals of the Yoruba language whose analysis will give are lots of insights about the counting system in the language. These issues will further enhance the teaching and learning of the Yoruba language and its comparison with some other languages. 


\subsection{Phonological Structure}

Phonology is a distinct aspect of language study because of its centrality of the development of any language right from its orthography design to its reconstruction.

There are some salient phonological observations which are of significant interest in the counting system of Yoruba. These observations can only be explained via the analysis of its linguistic structure. Some of these issues are phonological processes like consonant deletion, vowel elision (segment and suprasegment), assimilation, coalescence, denasalization and even free variation (phoneme identification).

\subsubsection{Coalescence}

This is a phonological process where two segments merge together to produce an entirely new segment distinct from the input. Coalescence is a term used in linguistics to refer to the coming together of linguistic units which were originally distinguishable. Bamgbose (1990) defines vowel coalescence as a combination of two contiguous (underlying) vowels whose output is a different vowel entirely. For example,

$$
\begin{aligned}
& \text { Ogún }+ \text { èjì }=\text { ogójì } \\
& \text { twenty two forty } \\
& \text { Ogún }+ \text { èta }=\text { ogoóta } \\
& \text { twenty three sixty }
\end{aligned}
$$

In the examples above, the underlined segments at the underlying level (nasalized and oral vowels) merge together to produce the oral vowels underlined at the surface level. Awobuluyi $(1983,1987)$ refers to this type of coalescence as coalescence by assimilation with the skeletal format below:

$$
\left(\begin{array}{l}
\text { high } \\
\text { back } \\
\text { rounded } \\
\text { nasal }
\end{array}\right)\left(\begin{array}{l}
\text { mid-high } \\
\text { front } \\
\text { unrounded } \\
\text { oral }
\end{array}\right) \stackrel{0}{\longrightarrow}\left(\begin{array}{l}
\text { high } \\
\text { back } \\
\text { rounded } \\
\text { oral }
\end{array}\right)
$$

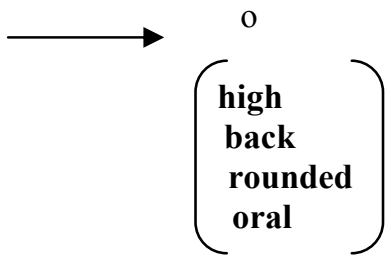

\subsubsection{Deletion}

Oyebade (2010) notes that deletion is one of the most obvious phonological processes in language. He notes that the process in Yoruba come about as a result of Yoruba preference for the shape and constitution of words. It is a term used to refer to the omission of sounds in connected speech. Both vowels and consonants may be affected.

\section{(A) Consonant deletion}
(i) irin owo

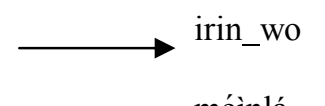
(ii) mẹrrìnlá

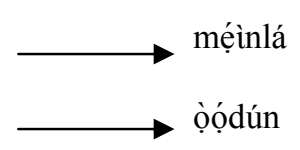
(iii) ọọodúnrún

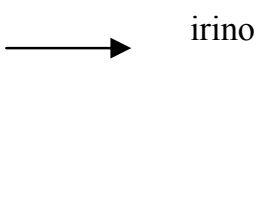

The above example (i) shows that consonant w got deleted amidst two vowels since the two vowels are rounded according to Oyebade (2010). Though there is an instance of vowel deletion too. In the example (ii), the consonant $\mathrm{r}$ is deleted, now at the beginning of the word unlike the assumption that it is usually in the last syllable of the word as in the example (iii) where consonant $\mathrm{r}$ is deleted in the last syllable (in fact the entire last syllable is deleted).

\section{(B) Vowel elision}

$$
\begin{aligned}
& \text { *ọgọ- + ọrún } \\
& 20 \times 5
\end{aligned}
$$

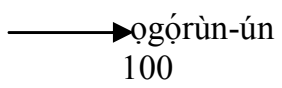

(*derivative of 20$)$

The deletion here is predictable; the vowel of the prefix is elided and its floating high tone displaces the low tone on the adjacent vowel /ọ/ and got docked to it.

$$
\begin{aligned}
& 16=\text { mẹ́rìndínlógún } \rightarrow \text { mẹindínlógún } \\
& 24=\text { merinlelogun } \rightarrow \text { mẹinlélógún } \\
& \text { mú }+ \text { èjì }=\text { méjì 'two' } \\
& \text { mú }+ \text { ẹ̀ta }=\text { mẹ́ta 'three' }
\end{aligned}
$$

It would be observed in the examples above that a consonant segment $/ \mathrm{r} /$ is deleted in the first two examples while a vowel sound $/ \mathrm{u} /$ is elided to derive unit forms of the numerals. The elision of sound may have been borne out of desire to ensure easy production of speech.

\subsection{3 (A) Tonal Sandhi}

Sequence of adjacent tones may influence each other phonetically or phonologically. In other words, a word which in isolation would have low tone may be given a higher tone if a high-tone word follows. This phenomenon, according to Crystal (2003) is referred to as tonal sandhi. Example of this is seen below 


\section{(B) Tonal changes}

Mú ọ̀kan lé ní ogún $\rightarrow$ mọ́kànlélógóún

There is no definite order for the occurrence of tone in Yoruba. Oyebade notes that tones occur indiscriminately. The pattern of tonal changes observed in the Yoruba counting system deserves some attention. It would be noted that cardinal numbers in the language (apart from kan 'one') start with high tones while ordinal numbers begin with low tones as shown in the table above.

$\begin{array}{cc}\text { Cardinal numbers } & \text { Ordinal numbers } \\ \text { méjì } & \text { ìèkejì } \\ \text { mẹ́tá } & \text { i/èkẹta } \\ \text { márùn-ún } & \text { i/ẹkarùn-ún }\end{array}$

\subsubsection{Denasalization}

Denasalization can be defined as the loss of underlying present nasality at the phonetic level. Awobuluyi and Oyebade (1995) note that many phonologists are of the opinion that nasalization is common and more natural than denasalization. As such, they tend to avoid any issue involving denasalization. The more frequent the occurrence of this phenomenon, the greater the need for its explanation. Denasalization according to Oyelaran (1976), Awobuluyi (1990) and Awobuluyi and Oyebade (1995) can occur under assimilation and deletion. The example below shows an instance of denasalization under deletion.
18 = mú-èjì-dín-ní-ogún

In the example above, there is an alternation of $\mathrm{n} / \mathrm{l}$ as in:

$$
\text { ní ogún } \longrightarrow \text { lógún }
$$

It has been argued that /1/ exist as an underlying segment having [n] and [1] as its surface variants. The [n] is converted to its oral (lateral) counterpart in an environment of an oral sound. The high tone on the deleted vowels $[\mathrm{u}]$ and [i] were docked on the contiguous vowel sound (after displacing the low tone on [e] in the first deletion) since tones do not get deleted with the segment. Tones are on a different tier independent of the segmental tier (Goldsmith 1976).

\subsubsection{Vowel assimilation}

Oyebade (1998) says assimilation refers to a situation where two contiguous sounds that have different ways of producing them become identical in some or all of the features of their production. For instance:

$$
\begin{aligned}
& \text { igba èjọ } \quad \longrightarrow \quad \text { egbẹjọ } \quad \text { '1600' } \\
& \text { igba ẹtàlá } \quad \longrightarrow \quad \text { egbẹ̀tàlá '2600' } \\
& \text { igba èje } \longrightarrow \quad \text { egbèje '1400' }
\end{aligned}
$$

This type of vowel assimilation, notes Oyebade (2010), is referred to as non-contiguous assimilation and it is regressive in direction.

\subsubsection{Free variation}

This is one of the phonological methods of identifying phonemes in a given language. It is a term used in phonology, referring to the substitutability of one sound for another in a given environment, with no consequent change in the word's meaning. Examples of this phenomenon are found in the Yoruba numerals;

$$
\left.\begin{array}{l}
\text { /i, e/ èkínní } \\
\text { /i, e/ } \\
\begin{array}{l}
\text { ìeẹ́ta } \\
\text { ẹkẹ́ta }
\end{array}
\end{array}\right\}^{\text {three }}
$$

\subsection{Morphological Structure}

\subsubsection{Clipping}

This is a morphological phenomenon whereby a word is shortened. The reduction could be at any part of the word such as the middle as in the examples below;

\subsubsection{Prefixation}

$$
\begin{aligned}
& 11=\text { oókànléléwàa }==\text { oókànlá 'one more than ten' } \\
& 12=\text { méjiléléwàá }==\text { méjilá } \quad \text { 'two more than ten' } \\
& 13=\text { métàlélewwà }==\text { mẹtàlá 'three more than ten' }
\end{aligned}
$$

We observe that affixes (bound morphemes) play some crucial role in the counting system of the Yoruba language. Two types of affixes are attested in Yoruba. These are prefixes and interfixes. Prefixes feature prominently in signaling increase by or decrease by of certain number. Some examples are given below: 
(i)

$$
\begin{aligned}
& \text { 'àádọ-', as in: } \\
& \begin{array}{c}
\text { àádọ- }+ \text { ọ̀ta }=\text { ààoọ- ọ̀ta 'fifty' } \\
-10 \quad \begin{array}{c}
(20 \times 3) \\
60-10=50
\end{array}
\end{array}
\end{aligned}
$$

$$
\begin{aligned}
& \text { àádọ́- }+ \text { ọ̀rìn }=\text { àádọ́rin 'seventy' } \\
& \begin{array}{l}
(20 \times 4) \\
\quad 80-10=70
\end{array}
\end{aligned}
$$

(iii) 'ogó-/ọọo-', as in:

$$
\begin{aligned}
& \text { ogó- }+ \text { èje }=\text { ogóje } \\
& 20 \times 7 \quad 140
\end{aligned}
$$

$$
\begin{array}{lll}
\text { ogọ́- } & \text { è̀fà }= & \text { ogọ́fà } \\
20 \text { x } 6 & 120
\end{array}
$$

(v) 'ẹgbẹ̀-', as in:

$$
\begin{aligned}
& \text { ẹgbẹ̀- + ẹ̀à }=\text { ẹgbẹfà } \\
& 200 \text { x } 6=600
\end{aligned}
$$

(vi) 'ẹẹẹẹ-’ as in:

$$
\begin{array}{ll}
\text { èẹdẹ́- }+ & \text { ẹgbèjọ = ẹẹdẹ́gbẹjọ } \\
-100 & (200 \times 8) \\
& 1600-100=1500
\end{array}
$$

(vii) ìk- + ẹ̀ta = ikẹ́ta

Ordinal marker three third (positional numeral)

(viii) ik- + ẹ̀à $=$ ìkẹfà

Ordinal marker six sixth (positional numeral)

\subsubsection{Language typology}

A pocket of examples so far can testify to the fact that the Yoruba language, to a large extent is an agglutinative language according to August Schlegel' 1818 morphological classification of languages. This is justified by the fact that morphemes combined in the sentential derivation are separable and they retain their distinct meanings. For instance;

$$
\begin{aligned}
& 17= \text { mú ọ̀kan dín ní ogún } \\
& \text { take one less in twenty } \\
& 34= \text { mú èrin lé ní ogbọ̀n } \\
& \text { take four more in thirty }
\end{aligned}
$$

\subsection{Syntactic structure}

There are examples of numerals performing the function of attributive position. However, the adjectives are known to occur after the noun which they modifying in the Yoruba language unlike the English language where they occur before the noun as shown below:

ìwé ogún ni mo rà 'I bought twenty books'

ilé ogbọ̀n ni mo kọ́ 'I built thirty houses'

But there are counter-examples where the numeral adjectives are found before the noun they modify.

\subsection{Semantic structure}

ogún ìwé ni mo rà 'It is twenty books that I bought'

$$
\text { ọbọ̀n ilé ni mo kọ́ 'it is thirty houses that I built' }
$$

Almost all the numerals in Yoruba have meanings that can be analyzed on morphemic basis. However, there are some numerals whose meanings appear arbitrary; there is no direct connection between them and the figure they depict. They are assigned basic status. According to Oyebade (2010), Yoruba has 1,2,3,4,5,6,7,8,9,10,20,30,200 and 400 as basic elements. They are not formed from other numbers. The meanings of some of them may have been borne out of their monetary implication which requires an excursion into the diachronic analysis of the Yoruba naira and kobo monetary system. Examples of such numbers are;

$$
\begin{aligned}
& 200=\text { igba } \\
& 400=\text { irinwó } \\
& 300=\text { ọọ́dúnrún }
\end{aligned}
$$

Whereas irinwo (400) could be analyzed as;

$$
\begin{aligned}
& \text { irin owó } \\
& \text { 'iron money' }
\end{aligned}
$$


The intuitive knowledge of a native speaker of the language is required to show that 'irinwó' means 'a huge amount of money’. But 2-10 (ệwá), 20 (ogún), 30 (ọgbọ̀n), 200 (igba) and 300 (ọọódúnrún) can not be analyzed. Their meanings are basically conventional.

\subsubsection{Ambiguity}

Semantic ambiguity is equally observed in the Yoruba numerals as given below;

$$
\text { ogún 'twenty' }
$$

ogún 'inheritance'

This ambiguity can create some communication problem for the second language learner.

\section{Summary of Findings and Conclusion}

This paper has presented a detailed description of the derivational processes in Yoruba numeral system with explanations on the derivational history of certain numerals whose meanings are not very obvious in the language as well as certain changes that have

occurred in the system over time.

It is indeed a truism that every language is rule-governed. In this paper, we discover that numeral in Yoruba requires some arithmetic in a way that it stimulates our intelligence. This might be one of the reasons why many people are not so interested in its learning. Besides, it appeals to our competence to know which affix to be attached to what number while counting the numbers that are even and odd. The counting system in the language is from right-to-left. In addition, Yoruba uses base five, decimal, and vigesimal (base twenty) counting system. Moreover, the Yoruba language is arbitrary and conventional. Arbitrary in the sense that there are some numbers whose meanings have no connection of any sort with the arithmetical calculation that produce them. Their acceptance is conventional. However, a good percentage of the numbers have meanings that are conceptual in form and their understanding could be interesting.

In the analysis, we discover that there are a number of linguistic insights in the structure of Yoruba numerals. And these linguistic features enrich the linguistic database of the language and facilitate the teaching and learning of the grammar of the language.

\section{References}

Atóyèbí, J. (n.d.). Oko numerals and their derivation. Paper presented at the Ph.D seminar at Max Planck Institute for Evolutionary Anthropology.

Awobuluyi, O. (1983). Iyoọpọ fáwẹẹlì: Ara amójúfò fonọlọjì Yorùbá. Lagos: Karounwi Lectures.

Awobuluyi, O. (1987). Towards a typology of coalescence. Journal of West African Languages. XVII, 2: 5-22.

Awobuluyi, O. (1990). On the N-L alternation in Yoruba. Paper read at the departmental seminar series, Department of Linguistics and Nigerian Languages, University of Ilorin.

Awobuiuyi, O. (1994). The development of standard Yoruba. In Istvan Fodor/Claude Hagege (Eds.) Language reform; History and future. Hamburg: Helmut Buske Verlag. (VI, 25 - 42).

Awobuluyi, O. and Oyebade, F. O. (1995). Denasalization in Yoruba: A non-linear Approach. In K. Owolabi (Ed.) Language in Nigeria: Essays in honour of Ayo Bamgbose. Ibadan: Group Publishers.

Bamgbose, A. (1990). Fonọloóji àti gírámà Yorùbá. Ibadan: University Press Ltd.

Esiri, E. (2011). Numeral system of Yoruba: Focus on the dialect of Oyo. An unpublished B.A. Dissertation.

Comrie, B. (2005). Numeral bases. In M. Haspelmath et al. (Eds.), The world atlas of language structures. Oxford: Oxford University Press. 530-533.

Comrie, B. (2006). Endangered numeral systems. Paper presented at Max Planck Institute for Evolutionary Anthropology.

Crystal, D. (2003). A dictionary of linguistics and phonetics. USA: Blackwell Publishing.

Everett, D. (2003). Documenting languages: A view from the Brazilian Amazon. In P. K. Austin (Ed.) Language documentation and description. (Vol. 1. 140-158).

Foley, W. (2004). Language endangerment, language documentation and capacity building: Challenges from New Guinea. In P. K. Austin (Ed.) Language documentation and description. ( Vol. 2. 28-38).

Goldsmith, J. (1976). Autosegmental phonology. London: MIT Press.

Girling, D.A. (1958). (Ed.) Everyman's encyclopaedia. (6 ${ }^{\text {th }}$ ed.). London: J.M. Dent \& Sons Ltd. (Vol.9, Pp.6970).

Himmelmann, N. (1998). Documentary and descriptive linguistics. Linguistics. 36: 161-195.

Jeje, A. (1979). Yorùbá fún ilé-ekọ gíga. Ibadan: Heinemann Educational Books.

Lounge, O. (2009). A vigesimal number system. Bookbuilders

Mitchell, J. (1976). (Ed.) Science and the universe: The joy of knowledge of encyclopaedia. London: Mitchell Beazley Encyclopaedia Ltd.

Oduyoye, M. (1969). Yoruba: Numeration system. Ibadan. Daystar Press.

Oyebade, F. O. (1998). A course in phonology. Ijebu-Ode: Shebotimo.

Oyebade, F. O. (2010). Yoruba phonology. In O. Yusuf (Ed.) Basic linguistics for Nigerian languages. Ijebu- 
Ode: Shebotimo.

Oyebade, F. O. (2010). The imperatives of documenting counting systems in African languages: A window into the cognitive process of computation. A lead paper presented at the 2nd University of Uyo Conference on African Languages held between September 19th and 24 th, 2010.

Oyelaran, O. (1976). Further notes on the alveolar nasal in Yoruba and phonological status of syllabic nasal. Paper read at the round table meeting on nasals and nasalization on generative phonology at the University of Ibadan.

Spencer, D. D. (1976). Computer science mathematics. Columbus: Charles E. Merrill Publishing Company.

The Oxford English dictionary ( $8^{\text {th }}$ ed.), (1933). London; Oxford University Press.

Woodbury, T. (2003). Defining documentary linguistics. In P. K. Austin (Ed.) Language documentation and description. (Vol. 1. 35-51). 